\title{
Understanding Complexity: the Curvilinear Relationship Between Environmental Performance and Firm Performance
}

\author{
Ramakrishnan Ramanathan ${ }^{1}$
}

Received: 24 June 2015/ Accepted: 7 February 2016/Published online: 26 February 2016

(C) The Author(s) 2016. This article is published with open access at Springerlink.com

\begin{abstract}
The nature of the relationship between environmental performance (EP) and firm performance (FP) of corporations is a long standing and contentious issue in the literature. This study is intended to advance this debate by arguing for the existence of curvilinear relationship and empirically testing the same using survey data on UK manufacturing firms. FP is captured in terms of growth in sales and market share. Our results show evidence for a quadratic relationship - as firms improve their EP, they seem to achieve much higher levels of FP. These results are consistent with the resource-based view of a firm; as firms engage in EP activities, they are able to gain inimitable knowledge that helps in further learning to further improve performance. Based on our results, we suggest that new studies focus on strategies to extend the period of increasing returns and maximizing the benefits of the positive association between EP and FP.
\end{abstract}

Keywords Environmental performance $\cdot$ Firm performance $\cdot$ Curvilinear relationship - The resourcebased view of a firm

\section{Introduction}

As society becomes more aware of negative impacts of economic development on the environment, increasingly stronger pressures are applied on organizations to improve their environmental performance (EP). Expenditure on

Ramakrishnan Ramanathan

ram.ramanathan@beds.ac.uk

1 Putteridge Bury Campus, University of Bedfordshire Business School, Hitching Road, Luton LU2 8LE, UK improved EP is typically viewed by firms as costs that correlate negatively with returns. However, a positive link between EP and firm performance (FP) would 'license companies to pursue the good-even by incurring additional costs-in order to enhance their bottom line and at the same time contribute more broadly to the well-being of society,' (Margolis et al. 2007) which explains the amount of research trying to positively link EP with FP. Investigation of this link has been the topic of several research studies in the past. A recent literature review on this topic is provided by Beurden and Gössling (2008). However, the available evidence is inconclusive; there are some studies that have found a positive link (e.g., Waddock and Graves 1997), some have found a negative link (e.g., Konar and Cohen 2001), while others have found no link at all (e.g., Berman et al. 1999). These conflicting findings have led researchers to look for more complex possibilities for the EP-FP relationship (Russo and Fouts 1997; Peloza 2006; Hull and Rothenberg 2008).

In order to comprehend the complexities, several researchers have attempted to understand the role of other relevant organizational variables in affecting the EP-FP relationship. For example, the mediating role of training has been established by Sarkis et al. (2010). The moderating role of complexity, uncertainty, and munificence has been studied by Rueda-Manzanares et al. (2008). Innovation plays a moderating role as shown by Eiadat et al. (2008), Hull and Rothenburg (2008), Jaffe and Palmer (1997), Montabon et al. (2007), and Triebswetter and Wackerbauer (2008).

We posit in this paper that the more complex relationship between EP of corporations and their FP could be curvilinear, specifically quadratic. This would mean that EP will moderate the link between EP and FP, supporting the approach taken by previous studies that attempted to 
study moderating roles of organizational variables. The moderating role of EP would imply that there is new learning and development of inimitable knowledge that helps further improving the performance. Our hypothesis is motivated by a recent study that identified similar curvilinear relationships between social responsibility and financial performance in the context of stock markets (mutual funds) (Barnett and Salomon 2006).

\section{Background and Theory on Environmental Performance-Firm Performance Link}

\section{Theory: the Resource-Based View of a Firm}

The resource-based view (RBV) of a firm has been suggested in the literature to understand the influence of EP on FP. This theory was originally developed to help understand how a firm can exploit its internal resources for sustained competitive advantage. Kraaijenbrink et al. (2010) have provided a detailed review of the RBV as a theoretical paradigm. RBV has rich reputation as the underlying theoretical principle linking EP with FP (e.g., Russo and Fouts 1997; Klassen and Whybark 1999; Hart 1995; Hart and Ahuja 1996; Sarkis et al. 2010; Menguc and Ozanne 2005). This theory explicitly discusses sources of financial bottom line in firms (Barney 1991; Wernerfelt 1984). In addition, it deals with intangible assets such as know-how and reputation that cannot be easily imitated by competition. A firm's capabilities or competencies and management's abilities to marshal these assets to produce superior performance determine competitive advantage (González-Benito and González-Benito 2005; RuedaManzanares et al. 2008). Companies with proactive EP generally accumulate valuable know-how on pollution prevention in the long run. This know-how is inimitable and will be the source for competitive advantage to the firm. This will often necessitate that the firm redesigns its production processes or service delivery processes to achieve maximum possible efficiency. New technologies may need to be developed or may be acquired from the market. The RBV helps in understanding the proactive development of newer efficient technologies by firms wishing to improve their EP. Even if the technologies are acquired from the market (which may not directly result in competitive advantage as the same technologies will be available to competitors as well), the RBV would help describe the efforts of operationally efficient firms to adapt the technologies for efficiency improvements (Russo and Fouts 1997). These efforts are unique to environmentally active firms and are not easily imitable. Thus, RBV generally supports the positive link between EP and FP. Using this theoretical lens, Russo and Fouts (1997) have highlighted that a proactive environmental policy will generate broader organizational competitive advantage for a firm. They have argued that the same policies that internalize negative environmental spillovers could also generate greater positive organizational spillovers that accrue internally and privately to the firm.

Thus, RBV generally supports existence of the EP-FP relationship due to appropriate deployment and utilization of resources in a firm. A relationship between EP and economic performance might be expected since both require the use of strategic resources required for competitiveness (Klassen and Whybark 1999). These strategic resources could include continuous improvement, stakeholder management (Hart 1995), physical assets and technology, organizational culture, inter-functional coordination, and other intangible resources (Russo and Fouts 1997). The positive association between EP and FP is also due to the abilities of firms with improved EP to attract and retain quality employees, reduce costs, and increase operational efficiency (Hart and Ahuja 1996).

Using meta-analysis of 52 previous studies, Orlitzky et al. (2003) found general support for a positive link between social performance and financial performance. The link has been empirically verified in some other studies (Filbeck and Gorman 2004; Majumdar and Marcus 2001). However, the direction of association (positive or negative) is inconclusive, with some studies showing a positive relationship (e.g., Boiral 2007) and others finding a negative relationship (e.g., Filbeck and Gorman 2004; Triebswetter and Hitchens 2005). These mixed results have prompted researchers to suggest that the link between EP and FP may not be straightforward but more complex; there could be some other factors that govern this relationship through complex moderating or mediating or similar roles (McWilliams and Siegel 2000). In the following sections, we first review studies that attempted to test the existence of direct relationship between EP and FP, and then review studies that attempted to identify more complex possibilities on this relationship.

\section{Evidence for a Relationship-Positive, Negative, or Neutral}

Literature has a plethora of studies on the link between EP and FP, and has come up with all the three possible results - positive relationship, negative relationship, and no (i.e., neutral) relationship.

The following studies, among others, have found evidence for a positive relationship: Hart and Ahuja (1996), Waddock and Graves (1997), Russo and Fouts (1997), Balabanis et al. (1998), Margolis and Walsh (2003), Orlitzky et al. (2003), Margolis et al. (2007), Montabon et al. (2007), Callan and Thomas (2009), Peloza (2009), Rugman 
and Verbeke (2000), Porter and Linde (1995a, b), Marshall and Brown (2003), and Preston (2001). More recent studies that found positive relationship between EP and FP include Tarus (2015) for Kenya, Lin et al. (2009) for Taiwan, Mishra and Suar (2010) for India, Hossain et al. (2015) for Bangladesh, Lisi (2015) for Italy, and Maletič et al. (2015) for multiple European countries (Germany, Poland, Serbia, Slovenia, and Spain). Hafez (2015) has found a weak positive (also neutral) link for the case of Egyptian banks, while Kamatra and Kartikaningdyah (2015) found a weak positive link for the case of Indonesian mining industry. 80 out of 95 studies reviewed by Margolis and Walsh (2001), and 109 of 127 studies reviewed by Margolis and Walsh (2003) have found positive association between EP and FP. In general, RBV supports positive association.

The following studies reported negative relationships: Brammer et al. (2006), Cordeiro and Sarkis (1997), Dobre et al. (2015), Filbeck and Gorman (2004), Konar and Cohen (2001), Moore (2001), Sarkis and Cordeiro (2001), and Lima Crisóstomo et al. (2011). A main argument for the existence of negative relationship is that firms trying to enhance EP draw resources and management effort away from core areas of the business, resulting in lower profits.

The following studies reported no evidence for a direct relationship between EP and FP: Aras et al. (2010), Jaffe et al. (1995), Johnson and Greening (1999), Berman et al. (1999), Chetty et al. (2015), McWilliams and Siegel (2000), Thornton et al. (2003), Elsayed and Paton (2005), and Vogel (2005). These studies generally claim that there is either no relationship between EP and FP, or if there is one, that it is too complex to be found (Margolis and Walsh 2003; Ullmann 1985).

\section{The Case for More Complex Relationships}

The complex nature of the relationship between environmental and FP (Peloza 2006; Hull and Rothenberg, 2008) may have been overlooked in past studies. Therefore, it is important to consider more complex possibilities (such as accounting for underlying organizational variables that possibly moderate or mediate) when examining this relationship (McWilliams and Siegel 2000; Schuler and Cording 2006; Eiadat et al. 2008).

Vogel (2005) suggested that the EP-FP relationship depends on the context of the specific issue at hand because specific circumstances would alter the nature of the relationship. For example, the role of good management skills in translating good environmental actions to profits has been highlighted (Schuler and Cording 2006; Peloza and Papania 2008). The indirect impact of the role of industry sector has been highlighted by Lopez-Gamero et al. (2009). For firms with shareholder value-oriented strategies, the relationship between EP and economic performance was more positive than for firms without such a strategy (Wagner and Schaltegger 2004).

In this paper, we argue that the complex nature of EPFP relationship could be curvilinear. There are anecdotal evidences to suggest that the relationship could be curvilinear. The curvilinear relationship can potentially account for all the three possibilities (positive, negative, or neutral) identified in the previous literature. Barnett and Salomon (2006) have identified curvilinear relationship between social responsibility and financial performance using data from stock market (mutual funds). The theory of Environmental Kuznets Curves (Stern 2004) suggests curvilinear relationships between environment improvement and performance at country level. These evidences are discussed in more detail in the next section.

\section{The Case for Curvilinear Relationships Between EP and FP}

The resource-based view of a firm highlights that valuable, rare, inimitable, and non-substitutable resources result in capabilities that help achieve competitive advantage. As per RBV, though any two firms may use the same commercially available equipment, the one using the equipment more innovatively and accumulating valuable knowledge that is inimitable will achieve better competitive advantage (Russo and Fouts 1997). Thus, the accumulation of valuable knowledge on technology and resources helps firms in increasing returns on their performance. Extending this logic to the case of the link between EP and FP, we argue that firms with moderate level of deployment of resources and capabilities in improving EP may be able to generate a moderate level of accumulated knowledge resulting in improved performance. Extending this idea further, firms with higher level of deployment of resources and capabilities in improving EP may be able to generate still higher level of accumulated knowledge that is more inimitable, resulting in much higher levels of improved performance. This could highlight increasing returns to scale, leading to curvilinear impacts on performance.

In addition to the support for curvilinear relationship based on the RBV theory, the literature studying the link between EP and FP has always been highlighting examples when increased knowledge on EP could lead to more effective investments, which in turn lead to more improvements in FP. For example, the distinction between pollution and prevention and pollution control in the environment technology portfolio of a firm has been highlighted by Klassen and Whybark (1999). Pollutioncontrol technologies are simple end-of-pipe solutions (usually from third party providers) that are relatively easy to implement. Other relatively easy pollution reducing 
solutions are the so called "low-hanging fruits," which basically involve better housekeeping (e.g., switching off lights when not needed or motion sensors to reduce water wastage in sinks). These may involve moderate levels of investments in order to improve EP. They may also have some positive impacts on FP. However, with continued accumulation of knowledge in pollution reduction, firms generally move to more effective pollution-prevention technologies, which involve redesigning manufacturing processes that involve the use of less raw materials and less energy leading to reduced pollution. In addition, the literature also suggests more effective pollution-prevention solutions in the form of continuous improvement, stakeholder management (Hart 1995), and organizational culture (Russo and Fouts 1997). Continuous improvement activities such as lean can help identify sources of waste on a regular basis and provide a regular opportunity to improve FP. An improved perception by stakeholders (such as employees or customers) will help in improved motivation (for employees) or improved patronage (for customers) leading to further improvements in FP. Similarly, lean implementation and more motivated employees will drive better organizational culture which will also have more positive impact on FP. All these examples support the possibility of curvilinear relationship between EP and FP.

The existence of curvilinear impacts has been tested in the literature beyond EP and FP, for example, in the case of knowledge creation (Badar et al. 2015) and in fairness perceptions in job satisfaction (Janssen 2001). Thus, we argue that existing levels of EP positively moderate the link between EP and FP, which implies a curvilinear (quadratic) relationship. This notion is somewhat supported by a recent study on the link between social performance and financial performance (Barnett and Salomon 2006) that found evidence for a curvilinear relationship in the context of mutual fund investments.

Thus, we hypothesize that the link between EP and FP could be curvilinear and that the link could be stronger at higher levels of EP due to higher levels of learning and accumulated inimitable know-how (Fig. 1). The following is our hypothesis.

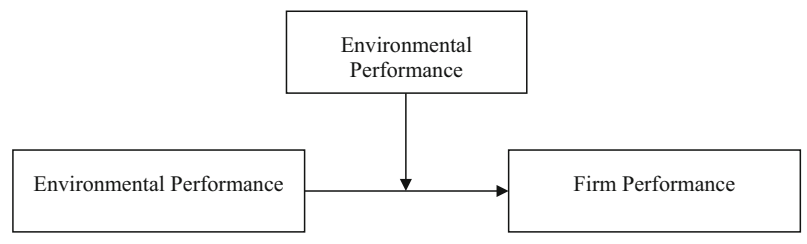

Fig. 1 Moderating effect of environmental performance on the relationship between environmental performance and firm performance
H1 EP positively moderates the relationship between EP and FP; the impact of EP on FP will be higher in firms with higher levels of EP.

\section{Reverse Causality of FP Influencing EP and the Endogeneity Issue}

Before discussing the survey and methods to verify the above hypothesis, it is important to discuss about the potential influence of FP on EP. When it is possible to conceive that $\mathrm{EP}$ influences $\mathrm{FP}$, it is equally possible to conceive the reverse causality, FP influencing EP. For example, at least conceptually, it is possible to think that financially stronger firms are able to invest more in EP, leading to a case for FP influencing EP. If this reverse causality is true, then our conceptual framework in Fig. 1 may suffer from endogeneity in the analysis of link between EP and FP. However, we believe the reverse causality, FP influencing EP, though theoretically plausible, does not have rigorous theoretical and empirical grounding in the literature. The following points provide arguments against the reverse causality.

1. Stakeholder theory (Freeman et al. 2010) has been extensively employed to suggest that EP is influenced by pressures from them. A variety of stakeholders, such as the internal stakeholders (employees, top management, etc.), have been identified in the literature (e.g., Delmas and Toffel 2008) but the financial position of a firm has not been exclusively identified as a driver for EP. There are arguments that FP, per se, does not influence EP but it is the top management support that is primarily responsible for helping firms improve EP. Even the link via top management appears weak because Francoeur et al. (2015) recently reported that environmentally conscious firms are not interested in paying premium compensation to their CEOs.

2. Even in environmentally proactive firms where top management commits to improving EP, the literature claims that very little research has been conducted so far on understanding how firms invest in specific managerial processes that translate into improved EP (Wisner et al. 2006).

3. Based on a qualitative study of 53 firms in the UK and Japan, Bansal and Roth (2000) have highlighted that main motivations for companies in improving their EP are competitiveness, legitimation, and ecological responsibility. There is no research that has highlighted that firms with high FP invest heavily in improving EP.

Hence we do not consider that there is a case for reverse causality and hence there is no endogeneity problem in the study reported in this paper. 


\section{Methods}

\section{Measures and Scale Development}

We developed our scales and measures by drawing from the previous academic and practitioner literature. A variety of conceptual measures have been proposed in the literature for EP (Zhu and Sarkis 2007; Montabon et al. 2007). Using these studies as the basis, we measured EP using two items: environmental certifications and self-evaluation of EP over the past 5 years. Similarly, based on the previous studies (Darnall et al. 2008; Tanriverdi and Lee 2008; Antoncic and Prodan 2008), FP has also been measured by self-evaluated measures of sales growth and improvement in market share. We prefer to call this construct as FP rather than financial performance because these are selfevaluated items using a Likert scale rather than objective financial measures (such as return on assets). Table 1 lists the measures and their literature sources used in this study. All the questions had 5-point Likert-type scales.

To control for the potential relationship between firm size and performance, we have included the number of employees reported by firms as a control variable (Brammer and Millington 2008). A single control variable for size is considered sufficient and it is unusual to include more than one variable to control for size. For example, Gray and Handley (2015) have used number of employees to measure firm size for use as a control variable in regression analysis. Panwar et al. (2015) have used turnover as control variable in regression, while Fontana et al. (2015) have used total assets as control variable in regression. Table 2 shows summary statistics for the variables of interest and the correlations between. All the analyses reported in this paper have been performed using SPSS (v19.0) statistical software.

\section{Sample Selection and Survey}

We conducted a questionnaire survey for collecting our data by contacting nearly 2000 manufacturing firms in the UK. In spite of reminders, we managed to get only 125 completed questionnaires. In order to improve sample size, we contacted another 1000 firms in February 2010 resulting in 50 more responses. However, after deleting unsatisfactory responses with significant missing data, the final sample size was 134 for use in subsequent analyses. We first performed $t$-tests to check substantial differences between the two sets of samples. Having found no statistically significant difference for all questions, we merged the two waves of questionnaires.

We tested for non-response bias (Armstrong and Overton 1977) using two ways. The first way was by comparing the responses of late respondents with those of early respondents. As mentioned above, there were no statistically significant differences between the two waves of questionnaires. The second way was by comparing data on the three organizational characteristics (2008 turnover, 2008 cost of sales, and 2008 total assets) of our respondent companies (totaling to 134) with corresponding data on all manufacturing firms in the UK (obtained from Financial Analysis Made Easy (FAME) Database). There were no statistically significant differences, confirming that nonresponse bias was not a serious problem with our survey.

As the study collected the data from a single respondent within each company, therefore, common method bias might exist. We tested such possibilities by employing Harman's one factor test (Sarkis et al. 2010; Darnall et al. 2008). The procedure is to carry out a factor analysis of all the items of interest without using factor rotation methods. If all variables load on one factor, common method bias exists (Doty and Glick 1998). In our case, a factor analysis resulted in two different factors, implying that there is no common method bias.

\section{Convergent Validity}

We verified convergent validity of our constructs using confirmatory factor analysis. Based on the previous quantitative studies, convergent validity has been verified in this paper in multiple ways-loading, average variance extracted (AVE), composite reliability (CR), and the significance of the Kaiser-Meyer-Olkin Measure of Sampling Adequacy (KMO). Details are available in Table 1.

Table 1 Results of factor analysis

\begin{tabular}{|c|c|c|c|c|}
\hline Name & Loading & $\begin{array}{l}\text { Average variance } \\
\text { extracted (AVE) }\end{array}$ & $\begin{array}{l}\text { Composite } \\
\text { reliability }\end{array}$ & $\begin{array}{l}\text { KMO } \\
\text { significance }\end{array}$ \\
\hline \multicolumn{5}{|l|}{ Environmental performance (based on Zhu and Sarkis 2007; Montabon et al. 2007) } \\
\hline Company has achieved important environment-related certifications & 0.842 & $71 \%$ & 0.823 & 0.000 \\
\hline On an average, environmental performance has improved over the last 5 years & 0.842 & & & \\
\hline \multicolumn{5}{|c|}{ Firm performance (Darnall et al. 2008; Tanriverdi and Lee 2008; Antoncic and Prodan 2008) } \\
\hline On an average, sales have been growing over the last 5 years & 0.957 & $92 \%$ & 0.957 & 0.000 \\
\hline On an average, company has increased its market share in the last 5 years & 0.957 & & & \\
\hline
\end{tabular}


Table 2 Summary statistics and correlation coefficients

\begin{tabular}{lllll}
\hline & 1 & 2 & 3 & 4 \\
\hline 1. Size & 1 & & \\
2. Firm performance & $0.320^{* *}$ & $\mathbf{0 . 9 5 9}^{\mathbf{a}}$ & & \\
3. Environmental performance & $0.282^{* *}$ & 0.125 & $\mathbf{0 . 8 4 3}$ & \\
4. Square of environmental performance & -0.068 & 0.141 & $-.344^{* *}$ & 1 \\
Minimum & 3 & -2.727 & -2.552 & 0 \\
Maximum & 5 & 1.484 & 1.330 & 6.51 \\
Mean & 4.75 & 0 & 0 & 0.993 \\
Std. deviation & 0.517 & 1 & 1 & 1.310 \\
\hline Diagonal values are in bold to highlight that they are not correlation coefficients & \\
a Diagonal values for firm performance and environmental performance are square root of AVE (to verify \\
discriminant validity) \\
$* *$ Correlation is significant at the 0.01 level (2-tailed)
\end{tabular}

Factor loadings of all the items are well above recommended limit of 0.4 (Hair et al. 2006). AVE values are all well above acceptable minimum value of $50 \%$ (Fornell and Larcker 1981). A significant Bartlett's Test of Sphericity value (i.e., significance value is 0.05 or smaller) of the KMO measure justifies the use of factor analysis (Pai and Huang 2011). Both the constructs have been found to have significant KMO measure. Further, the composite reliability has been checked for the consistency of our constructs. The calculated composite reliability values were well above the suggested minimum of 0.65 . Thus, our measures satisfy the statistical requirements for construct validity.

\section{Discriminant Validity}

Discriminant validity is needed because the constructs in our statistical models should measure different constructs and should not measure the same information. We tested for discriminant validity by checking the correlation between the constructs and comparing them with the square root of AVE of these two constructs (Fornell and Larcker 1981; Wong et al. 2011). Results, as reported in Table 2, show that the square roots of AVE of the two constructs ( 0.959 for FP and 0.843 for EP) (given in bold in the diagonal of the matrix) are greater than the correlation between them $(0.125)$, indicating that there is a satisfactory level of discriminant validity.

\section{Analysis and Results}

The hypotheses developed were tested using hierarchical regression because of the need to assess the marginal predictive contribution of the theoretical variables over and above that of the control variable. Recall that we framed our hypothesis in terms of moderating impacts of EP on EP-FP link; it says that the relationship between EP and FP would be higher at higher values of EP. In other words, the
$\mathrm{EP}-\mathrm{FP}$ link is positively moderated by $\mathrm{EP}$, and hence the curvilinear relationship is tested using moderating regression analysis (Hair et al. 2006; Li and Atuahene-Gima 2001; Miles and Shevlin 2001).

For the regressions discussed below, we first carried out the usual tests to check whether the assumptions of regression are valid for the data. We have tested for normality assumption of the error terms and checked for heteroskedasticity.

\section{Moderated Regression Analysis Results}

To verify the moderating influence of EP on the relationship between EP and FP, we carried out a moderated regression analysis (Hair et al. 2006; Li and AtuaheneGima 2001; Sanchez and McKinley 1998). In a moderated regression, a dependent variable is regressed on control variables, independent variables, moderator variables, and product terms of the independent and the moderator variables (Hair et al. 2006). The impact of the moderator variable is assessed using a two-stage regression $(\mathrm{Li}$ and Atuahene-Gima 2001; Sanchez and McKinley 1998). In the first stage, the dependent variable is regressed with the independent variables, moderator variables, and control variables (if any). In the second stage, a product term (independent $\times$ moderator variable) is added. The impact of the moderator is assessed based on the improvement in $R^{2}$ in the second stage regression over the first stage. If this change is statistically significant (using an $F$ test), then a significant moderator effect is predicted (Hair et al. 2006). Hair et al. (2006) further suggest that only the incremental effect (the product term) is assessed for checking the significance of the moderation effect, and the significance of individual variables is not considered relevant.

The results of the analysis to test the moderating effect of EP on the relationship between EP and FP are presented in Table 3. Since EP is both the independent variable and 
the moderator variable, we have not introduced a separate moderator variable in stage 1 regression. As mentioned earlier, moderated regression analysis involves the use of a product term of the independent variable (EP) and the moderator variable (also $\mathrm{EP}$ ) in stage 2, which is a square term $\left(\mathrm{EP}^{2}\right)$ representing curvilinear relationship.

The results presented in Table 3 show that the coefficient of the square term $\left(\mathrm{EP}^{2}\right)$ is positive $(0.187)$ and significant $(p<0.05)$. This confirms the strong positive moderating impact of EP on EP-FP link. Thus, results of Table 3 strongly support our hypothesis that EP affects FP more positively for firms with higher EP.

\section{Discussion}

Our results show a strong support for the curvilinear relationship between EP and FP. The relationship is sketched in Fig. 2. This finding is somewhat supported by the findings of Barnett and Salomon (2006) who have found a similar curvilinear relationship between social responsibility and financial performance in the context of stockmarket data.

We believe that the positive curvilinear relationship makes sense in the context of the relationship between EP and FP. We highlighted how the basic tenets of RBV (namely inimitable accumulated knowledge) could be used to support our hypothesis in Sect. 2. We elaborate the idea further here.

The direct relationship between EP and FP could indicate that a number of environmental initiatives (such as waste reduction and putting off lights when not needed) also have positive impact on the financial bottom line. For example, efforts to reduce waste would mean avoiding excess raw material in the first place, resulting in reduced

Table 3 Regression results (standardized coefficients) for the moderating effect of environmental performance on the relationship between environmental performance and firm performance

\begin{tabular}{lll}
\hline Dependent variable: firm performance & & \\
\hline \multicolumn{1}{c}{ Independent variables } & Stage1 & Stage2 \\
\hline Control: size & 0.047 & 0.111 \\
Direct effect: & $0.307^{* * *}$ & $0.302^{* * *}$ \\
$\quad$ Environmental performance & & \\
Moderating effect: & & $0.187^{* *}$ \\
$\quad$ Square of environmental performance & & \\
$R^{2}$ & 0.105 & 0.135 \\
$R_{\text {adj }}^{2}$ & 0.091 & 0.115 \\
$\Delta R^{2}$ & & $0.031^{* *}$ \\
$F$ & $7.47^{* * *}$ & $6.63^{* * *}$ \\
\hline
\end{tabular}

$* p<0.1 ; * * p<0.05 ; * * * p<.0 .01$

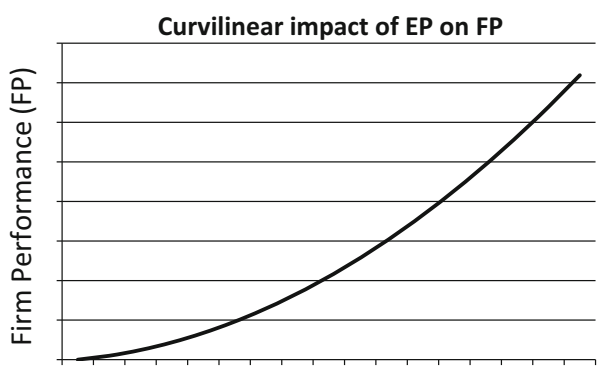

Environmental performance (EP)

Fig. 2 Curvilinear impact of environmental performance on firm performance

raw material cost and hence in improved performance. 'Low-hanging fruits' in terms of their initial success with EP (Toffel and Lee 2009) will result in proportional improvement in FP. Specifically, a number of simple housekeeping measures (e.g., switching off lights) can help companies reduce waste, which will help improve EP and FP proportionately. As RBV suggests, once certain level of knowledge in using resources and capabilities on EP has been accumulated, the existing pool of knowledge may result in larger levels of accumulated knowledge and innovation. Thus, once there is increased knowledge on how to reduce waste and increased understanding of more integrated/innovative methods of reducing environmental impacts (e.g., lean implementation, continuous improvement and eco-friendly design of products and processes as highlighted by several researchers such as King and Lenox (2001), Klassen and Whybark (1999), Melnyk et al. (2003), and Toffel and Lee (2009), EP is likely to provide more than proportional level of improvement in FP. Thus, the case for curvilinear (quadratic) relationship is established.

In addition, environmentally active firms are able to leverage more from their existing eco-friendly activities in the form of increased market leadership and also in the form of reduced environmental regulatory liabilities (Godfrey et al. 2009). In addition to economic benefits through increased sales and reduced costs, an improved EP can also provide a firm with benefits of avoiding potential mitigation of harmful events (Peloza 2006). Since pollution levels are increasingly critical, any environmental incident may tarnish a firm's reputation in addition to subjecting it to substantial legal costs and fines (Eiadat et al. 2008) which can have significant impacts on financial performance. As a firm makes strategic investments that reduce emissions and pollution, it mitigates its risk of litigation (Sharfman and Fernando 2008). All these additional benefits could indicate that improved EP could provide more than proportional improvement in FP in the long term, establishing the existence of curvilinear positive impacts.

We believe that identification of curvilinear relationship has provided an interesting framework to look at the results 
of previous studies and thus has extended the existing debate on the relationships between EP and FP. In spite of its interesting findings, our study could be improved further. First, we used primary data based on subjective opinions of respondents in our study. Future studies can take up objective measures (e.g., pollution expenditure for EP and return on assets for financial performance). Previous studies have shown that only pollution-prevention efforts (i.e., integrating waste minimization in design of processes) and not pollution control (such as end-of-pipe cleanup) will result in improvements in financial performance (Klassen and Whybark 1999; King and Lenox 2002). Hence, more interesting results could emerge if primary/secondary data are collected in terms of pollution-prevention and pollution-control expenditure. Though we have focused only on EP as a variable affecting the link between EP and FP, we do believe that other variables may also have important effects. For example, the increasing requirements from the governments to reduce pollutions though legislations could be an important reason for firms in accelerating further investments in EP. The impact of these variables should be studied. These studies will form scope for future research. Finally, it would be interesting to test the curvilinear relationship in different country contexts.

\section{Theoretical and Managerial Implications}

Since past studies on the relationship between EP and FP have been inconclusive, there is a general recognition in the literature that this relationship could be more complex (Peloza 2009). Responding to the call for more detailed studies on investigating the mechanisms or routes through which EP can lead to FP, we have hypothesized a curvilinear relationship between EP and financial performance and tested the relationship empirically using primary data from UK manufacturing firms.

We believe that our results support the RBV as a theoretical paradigm. This theory supports the use of internal resources to achieve sustained competitive advantage. An environmentally proactive firm will undertake conscious and systemic efforts in improving efficiencies of its production and service delivery processes. These efforts accumulate over time to a set of wealthy knowledge and translate into internal competitive advantages, which cannot be imitated by competitors (Russo and Fouts 1997). This accumulated knowledge to accelerate the positive impact of EP on FP, leading to positive curvilinear relationship. Our results should provide good encouragement to firms that are taking their active efforts in improving their EP; their efforts will have better impacts on financial performance compared to an environmentally less active firm. Our results not only support the strategic need for harnessing internal resources to meet external demands (Collis and Montgomery 1995) but also show that there are increasing returns from environmental investments as EP improves.

Two proponents of RBV have identified key specific organizational resources that would link EP with FP in firms: Hart (1995) has argued for continuous improvement and stakeholder management, while Russo and Fouts (1997) extended this set to include the deployment of physical assets and technology, organizational culture, inter-functional coordination, and intangible resources such as appeal to green customer segments and political acumen. We believe that some of these resources-physical assets and technology-may yield faster financial benefits than others leading to closer links with FP compared to others (continuous improvement, stakeholder management, etc.) that will require additional investments but more pronounced returns leading to curvilinear relationships between EP and FP.

In summary, our study has extended the applicability of the RBV of the firm. RBV has already been applied to understand the links between EP and corporate performance (e.g., Russo and Fouts 1997; Hart 1995), but our study extends the RBV to understanding the more complex curvilinear relationships. We believe that our study highlights the greater breadth of the applicability of the RBV to understand the role of internal capabilities and processes in giving competitive edge to firms.

Our study has practical implications for managers. Investments in EP (e.g., waste reduction) can yield positive returns in terms of FP initially, but it will be encouraging for managers that accumulated expertise on existing environmental investments could lead to more accelerated improvements in FP. It can provide insurance against litigations (Sharfman and Fernando 2008). Such proactive investments in improving EP can also be useful to managers to meet the obligations of environmental regulations and even stay ahead of the regulations (Porter and Linde 1995).

In conclusion, we believe that our finding of the existence of a curvilinear relationship between EP and FP has uncovered some new knowledge in the seemingly conflicting findings about the positive/negative/neutral relationships. We look forward to future studies that will improve upon our contribution by using more elaborate datasets. For example, we realize that the positive curvilinear impact may not continue forever and the limits to this relationship should be further explored in future studies.

Open Access This article is distributed under the terms of the Creative Commons Attribution 4.0 International License (http://crea tivecommons.org/licenses/by/4.0/), which permits unrestricted use, distribution, and reproduction in any medium, provided you give appropriate credit to the original author(s) and the source, provide a link to the Creative Commons license, and indicate if changes were made. 


\section{References}

Antoncic, B., \& Prodan, I. (2008). Alliances, corporate technological entrepreneurship and firm performance: Testing a model on manufacturing firms. Technovation, 28, 257-265.

Aras, G., Aybars, A., \& Kuthu, O. (2010). Managing corporate performance: Investigating the relationship between corporate social responsibility and financial performance in emerging markets. International Journal of Productivity and Performance Management, 59(3), 229-254.

Armstrong, J. S. \& T. S. Overton. (1977) 'Estimating nonresponse bias in mail surveys'. Journal of Marketing Research. 396-402.

Badar, K., Hite, J. M., \& Ashraf, N. (2015), 'Knowledge network centrality, formal rank and research performance: evidence for curvilinear and interaction effects', Scientometrics, (in press). DOI 10.1007/s11192-015-1652-0.

Balabanis, G., Phillips, H. C., \& Lyall, J. (1998). Corporate social responsibility and economic performance of top British companies: Are they linked. European Business Review, 98(1), 25-44.

Bansal, P., \& Roth, K. (2000). Why companies go green: A model of ecological responsiveness. Academy of Management Journal, 43(4), 717-736.

Barnett, M. L., \& Salomon, R. M. (2006). Beyond dichotomy: The curvilinear relationship between social responsibility and financial performance. Strategic Management Journal, 27(11), 1101-1122.

Barney, J. (1991). Firm resources and sustained competitive advantage. Journal of Management, 17, 99-120.

Berman, S. L., Wicks, A. C., Kotha, S., \& Jones, T. M. (1999). Does stakeholder orientation matter? The relationship between stakeholder management models and firm performance. Academy of Management Journal, 42(5), 488-506.

Boiral, O. (2007). Corporate greening through ISO 14001: A rational myth. Organization Science, 18, 127-146.

Brammer, S., Brooks, C., \& Pavelin, S. (2006). Corporate social performance and stock returns: UK evidence from disaggregate measures. Financial Management, 35(3), 97-116.

Brammer, S., \& Millington, A. (2008). Does it pay to be different? An analysis of the relationship between corporate social and financial performance. Strategic Management Journal, 29(12), $1325-1343$.

Callan, S. J., \& Thomas, J. M. (2009). Corporate financial performance and corporate social performance: An update and reinvestigation. Corporate Social Responsibility and Environmental Management, 16, 61-78.

Chetty, S., Naidoo, R., \& Seetharam, Y. (2015). The impact of corporate social responsibility on firms' financial performance in South Africa. Contemporary Economics, 9(2), 193-214.

Collis, D. J., \& Montgomery, C. A. (1995) 'Competing on resources: Strategy in the 1990 s' knowledge and strategy 25-40.

Cordeiro, J. J., \& Sarkis, J. (1997). Environmental proactivism and firm performance: Evidence from security analyst earnings forecasts. Business Strategy and the Environment, 6, 104-114.

Darnall, N., Henriques, I., \& Sadorsky, P. (2008). Do environmental management systems improve business performance in an international setting. Journal of International Management, 14, 364-476.

Delmas, M. A., \& Toffel, M. W. (2008). Organisational responses to environmental demands. Strategic Management Journal, 29, 1027-1055.

Dobre, E., Stanila, G. O., \& Brad, L. (2015). The influence of environmental and social performance on financial performance: Evidence from Romania's listed entities. Sustainability (Switzerland), 7(3), 2513-2553.

Doty, D. H., \& Glick, W. H. (1998). Common methods bias: does common methods variance really bias results. Organizational Research Methods, 1(4), 374-406.
Eiadat, Y., Kelly, A., Roche, F., \& Eyadat, H. (2008). Green and competitive? An empirical test of the mediating role of environmental innovation strategy. Journal of World Business, 43, 131-145.

Elsayed, K., \& Paton, D. (2005). The impact of environmental performance on firm performance: static and dynamic panel data evidence. Structural Change and Economic Dynamics, 16, $395-412$.

Filbeck, G., \& Gorman, R. F. (2004). The relationship between environmental and financial performance of public utilities. Environmental Resource and Economics, 29, 137-157.

Fontana, S., D’Amico, E., Coluccia, D., \& Solimene, S. (2015). Does environmental performance affect companies' environmental disclosure. Measuring Business Excellence, 19(3), 42-57.

Fornell, C., \& Larcker, D. F. (1981). Evaluating structural equation models with unobservable variables and measurement error. Journal of Marketing Research, 18(1), 39-50.

Francoeur, C., Melis, A., Gaia, S., \& Aresu, S. (2015). Green or greed? An alternative look at CEO compensation and corporate environmental commitment. Journal of Business Ethics, (In press).

Freeman, R. E., Harrison, J. S., Wicks, A. C., Parmar, B., \& de Colle, S. (2010). Stakeholder theory: The state of the art, Cambridge University Press.

Godfrey, P. C., Merrill, C. B., \& Hansen, J. M. (2009). The relationship between corporate social responsibility and shareholder value: An empirical test of the risk management hypothesis. Strategic Management Journal, 30(4), 425-445.

González-Benito, J., \& González-Benito, O. (2005). An analysis of the relationship between environmental motivations and ISO14001 certification. British Journal of Management, 16(2), 133-148.

Gray, J. V., \& Handley, S. M. (2015). Managing contract manufacturer quality in the presence of performance ambiguity. Journal of Operations Management, 38, 41-55.

Hafez, H. M. (2015). Corporate social responsibility and financial performance: An empirical study on Egyptian banks. Corporate Ownership and Control, 12(2), 107-127.

Hair, F. J., Black, W. C., Babin, B. J., Anderson, R. E., \& Tatham, R. L. (2006). Multivariate data analysis (6th ed.). New Jersey: Pearson Prentice Hall.

Hart, S. L. (1995). A natural resource-based view of the firm. Academy of Management Review, 20, 986-1014.

Hart, S. L., \& Ahuja, G. (1996). Does it pay to be green? An empirical examination of the relationship between emission reduction and firm performance. Business Strategy and the Environment, 5, $30-37$.

Hossain, M., Chowdhury, M. H., Evans, R., \& Lema, A. C. (2015). The relationship between corporate social responsibility and corporate financial performance: Evidence from a developing country. Corporate Ownership and Control, 12, 474-487.

Hull, C. E., \& Rothenburg, S. (2008). Firm performance: The interactions of corporate social performance with innovation and industry differentiation. Strategic Management Journal, 29, 781-789.

Jaffe, A. B., \& Palmer, K. (1997). Environmental regulation and innovation: A panel data study. Review of Economics and Statistics, 79(4), 610-619.

Jaffe, A. B., Peterson, S. R., Portney, P. R., \& Stavins, R. N. (1995). Environmental regulation and the competiveness of US manufacturing: what does the evidence tell us. Journal of Economic Literature, 33, 132-163.

Janssen, O. (2001). Fairness perceptions as a moderator in the curvilinear relationships between job demands, and job performance and job satisfaction. Academy of Management Journal, 44(5), 1039-1050. 
Johnson, R. A., \& Greening, D. W. (1999). The effects of corporate governance and institutional ownership types on corporate social performance. Academy of Management Journal, 42(5), 564-576.

Kamatra, N., \& Kartikaningdyah, E. (2015). Effect corporate social responsibility on financial performance. International Journal of Economics and Financial Issues, 5, 157-164.

King, A., \& Lenox, M. J. (2001). Lean and green? An empirical examination of the relationship between lean production and environmental performance. Production and Operations Management, 10(3), 244-256.

King, A., \& Lenox, M. J. (2002). Exploring the locus of profitable pollution reduction. Management Science, 48(2), 289-299.

Klassen, R. D., \& Whybark, D. C. (1999). The impact of environmental technologies on manufacturing performance. Academy of Management Journal, 42(6), 599-615.

Konar, S., \& Cohen, M. A. (2001). Does the market value environmental performance. Review of Economics and Statistics, 83(2), 281-289.

Kraaijenbrink, J., Spender, J.-C., \& Groen, A. J. (2010). The resourcebased view: A review and assessment of its critiques. Journal of Management, 36(1), 349-372.

Li, H., \& Atuahene-Gima, K. (2001). Product innovation strategy and the performance of new technology ventures in China. Academy of Management Journal, 44(6), 1123-1134.

Lima Crisóstomo, V., de Souza Freire, F., \& Cortes de Vasconcellos, F. (2011). Corporate social responsibility, firm value and financial performance in Brazil. Social Responsibility Journal, 7(2), 295-309.

Lin, C. H., Yang, H. L., \& Liou, D. Y. (2009). The impact of corporate social responsibility on financial performance: Evidence from business in Taiwan. Technology in Society, 31(1), $56-63$.

Lisi, I. E. (2015), Translating environmental motivations into performance: The role of environmental performance measurement systems, Management Accounting Research, (In press).

Lopez-Gamero, M. D., Molina-Azorin, J. F., \& Claver-Cortez, E. (2009). The whole relationship between environmental variables and firm performance: Competitive advantage and firm resources as mediator variables. Journal of Environmental Management, 90(10), 3110-3121.

Majumdar, S. K., \& Marcus, A. A. (2001). Rules versus discretion: The productivity consequences of flexible regulation. Academy of Management Journal, 44, 170-179.

Maletič, M., Maletič, D., Dahlgaard, J. J., Dahlgaard-Park, S. M., \& Gomišček, B. (2015). Effect of sustainability-oriented innovation practices on the overall organisational performance: An empirical examination. Total Quality Management and Business Excellence (In press).

Margolis, J., Elfenbein, H. A., \& Walsh, J. (2007). 'Does It pay to be good? A meta-analysis and redirection of research on the relationship between corporate social and financial performance', mimeo. Boston: Harvard Business School Press.

Margolis, J. D., \& Walsh, J. P. (2001). People and profits? The search for a link between a company's social and financial performance. Mahwah: Lawrence Erlbaum Associates.

Margolis, J. D., \& Walsh, J. P. (2003). Misery loves companies: Rethinking social initiatives by business. Administrative Science Quarterly, 48, 268-305.

Marshall, R. S., \& Brown, D. (2003). The strategy of sustainability: A systems perspective on environmental initiatives. California Management Review, 46(1), 101-126.

McWilliams, A., \& Siegel, D. (2000). Corporate social responsibility and financial performance: Correlation or misspecification. Strategic Management Journal, 21, 603-609.

Melnyk, S. A., Sroufe, R. P., \& Calantone, R. L. (2003). Assessing the impact of environmental management systems on corporate and environmental performance. Journal of Operations Management, 21, 329-351.

Menguc, B., \& Ozanne, L. K. (2005). Challenges of the "green imperative": a natural resource-based approach to the environmental orientation-business performance relationship. Journal of Business Research, 58(4), 430-438.

Miles, J., \& Shevlin, M. (2001). Applying regression and correlation: A guide for students and researchers. London: Sage.

Mishra, S., \& Suar, D. (2010). Does corporate social responsibility influence firm performance of Indian companies. Journal of Business Ethics, 95(4), 571-601.

Montabon, F., Sroufe, R., \& Narasimhan, R. (2007). An examination of corporate reporting, environmental management practices and firm performance. Journal of Operations Management, 25, 998-1014.

Moore, G. (2001). Corporate social and financial performance: An investigation of the UK supermarket industry. Journal of Business Ethics, 34, 299-315.

Orlitzky, M., Schmidt, F. L., \& Rynes, S. L. (2003). Corporate social and financial performance: A meta-analysis. Organisation Studies, 24(3), 403-441.

Pai, F. Y., \& Huang, K. I. (2011). Applying the technology acceptance model to the introduction of healthcare information systems. Technological Forecasting and Social Change, 78, 650-660.

Panwar, R., Nybakk, E., Pinkse, J., \& Hansen, E. (2015). Being good when not doing well: Examining the effect of the economic downturn on small manufacturing firms' ongoing sustainabilityoriented initiatives. Organization and Environment, 28(2), 204-222.

Peloza, J. (2006). Using corporate social responsibility as insurance for financial performance. California Management Review, $48(2), 52-72$.

Peloza, J. (2009). The challenge of measuring financial impacts from investments in corporate social performance. Journal of Management, 35(6), 1518-1541.

Peloza, J., \& Papania, L. (2008). The link between corporate social responsibility and financial performance: Stakeholder salience and identification. Corporate Reputation Review, 11(2), 169-181.

Porter, M. E. \& van der Linde, C. (1995a). 'Green and competitive: Ending the stalemate', Harvard Business Review Sept-Oct, $120-134$.

Porter, M. E., \& van der Linde, C. (1995b). Toward a new conception of the environment-competitiveness relationship. Journal of Economic Perspectives, 9(4), 97-118.

Preston, L. (2001). Sustainability at Hewlett-Packard: From theory to practice. California Management Review, 43(3), 26-37.

Rueda-Manzanares, A., Aragón-Correa, J. A., \& Sharma, S. (2008). The influence of stakeholders on the environmental strategy of service firms: The moderating effects of complexity, uncertainty and munificence. British Journal of Management, 19(2), $185-203$.

Rugman, A. M., \& Verbeke, A. (2000). Six cases of corporate strategic responses to environmental regulation. European Management Journal, 18(4), 377-385.

Russo, M. V., \& Fouts, P. A. (1997). A resource-based perspective on corporate environmental performance and profitability. Academy of Management Journal, 40(3), 534-559.

Sanchez, C. M., \& McKinley, W. (1998). Environmental regulatory influence and product innovation: The contingency effects of organisational characteristics. Journal of Engineering and Technology Management, 15, 257-278.

Sarkis, J., \& Cordeiro, J. J. (2001). An empirical evaluation of environmental efficiencies and firm performance: Pollution prevention technologies versus end-of-pipe practice. European Journal of Operational Research, 135, 102-113. 
Sarkis, J., Gonzalez-Torre, P., \& Adenso-Diaz, B. (2010). Stakeholder pressure and the adoption of environmental practices: The mediating effect of training. Journal of Operations Management, $28,163-176$.

Schuler, D. A., \& Cording, M. (2006). A corporate social performance-corporate financial performance behavioural model for consumers. Academy of Management Review, 31(3), 540-558.

Sharfman, M. P., \& Fernando, C. S. (2008). Environmental risk management and the cost of capital. Strategic Management Journal, 29(6), 569-592.

Stern, D. (2004). The rise and fall of the environmental Kuznets curve. World Development, 32(8), 1419-1439.

Tanriverdi, H., \& Lee, C.-H. (2008). Within-industry diversification and firm performance in the presence of network externalities: Evidence from the software industry. Academy of Management Journal, 51(2), 381-397.

Tarus, D. K. (2015). Corporate social responsibility engagement in Kenya: Bottom line or rhetoric? Journal of African Business, (In press).

Thornton, D., Kagan, R. A., \& Gunningham, N. (2003). Sources of corporate environmental performance. California Management Review, 46(1), 127-141.

Toffel, M., \& Lee, K. (2009). Sustainability at Millipore. Harvard Business Publishing, ECCH Case Reference: 9-610-012.

Triebswetter, U., \& Hitchens, D. (2005). The impact of environmental regulation on the competitiveness in the German manufacturing industry-a comparison with other countries in the European Union. Journal of Cleaner Production, 13, 733-745.

Triebswetter, U., \& Wackerbauer, J. (2008). Integrated environmental product innovation in the region of Munich and its impact on company competitiveness. Journal of Cleaner Production, 16, 1484-1493.
Ullmann, A. A. (1985). Data in search of a theory: A critical examination of the relationships among social performance, social disclosure, and economic performance of U.S. firms. Academy of Management Review, 10(3), 540-557.

Van Beurden, P., \& Gössling, T. (2008). The worth of values-a literature review on the relation between corporate social and financial performance. Journal of Business Ethics, 82(2), 407-424.

Vogel, D. J. (2005). Is there a market for virtue? The business case for corporate social responsibility. California Management Review, 47(4), 19-45.

Waddock, S. A., \& Graves, S. B. (1997). The corporate social performance-financial performance link. Strategic Management Journal, 18(4), 303-319.

Wagner, M., \& Schaltegger, S. (2004). The effect of corporate environmental strategy choice and environmental performance on competitiveness and economic performance: An empirical study of EU manufacturing. European Management Journal, 22(5), 557-572.

Wernerfelt, B. (1984). A resource-based view of the firm. Strategic Management Journal, 5, 171-180.

Wisner, P. S., Epstein, M. J., \& Bagozzi, R. P. (2006). Organizational antecedents and consequences of environmental performance. Advances in Environmental Accounting and Management, 3, 143-167.

Wong, C. Y., Boon-Itt, S., \& Wong, C. W. (2011). The contingency effects of environmental uncertainty on the relationship between supply chain integration and operational performance. Journal of Operations Management, 29(6), 604-615.

Zhu, Q., \& Sarkis, J. (2007). The moderating effects of institutional pressures on emergent green supply chain practices and performance. International Journal of Production Research, 45(18-19), 4333-4355. 